\title{
取扱い環境により容易に転移するチアミン塩化物塩酸塩の擬似結晶多形の識別手法
}

\author{
山田彩乃, ${ }^{*}$ 村尾 渚, 佐藤明啓, 藤本雄三, 中川ゆかり, 谷本 剛
}

\section{Identification Methods for Pseudo-crystalline Polymorphs of Thiamine Chloride Hydrochloride, Which Transform Easily Depending on the Handling Environment}

\author{
Ayano Yamada, ${ }^{*}$ Nagisa Murao, Akihiro Sato, Yuzo Fujimoto, Yukari Nakagawa, and Tsuyoshi Tanimoto \\ Pharmaceutical and Medical Device Regulatory Science Society of Japan, Pharmaceutical Reference \\ Standards Center; Sawanotsuru Bldg., 2-1-2 Hiranomachi, Chuo-ku, Osaka 541-0046, Japan.
}

(Received October 20, 2021; Accepted November 17, 2021)

\begin{abstract}
Three forms of pseudo-crystalline polymorph of thiamine chloride hydrochloride are dependent on hydration states. We investigated how the measurement environment affects the transition of the pseudo-crystalline polymorph, and aimed to establish a reliable method of identifying the forms clearly by IR spectrophotometry. We prepared three pseudo-crystalline forms and compared their IR spectra. In the IR spectra obtained by the potassium chloride ( $\mathrm{KCl}$ ) disk method, Form II was identified based on its characteristic absorption, but Forms I and III could not be distinguished clearly. Form I transformed to Form III after mixing with undried $\mathrm{KCl}$ powder, and Form III transformed to Form I by simply being left in the laboratory environment. These results suggested that the reversible transformation between Forms I and III occurred depending on the hydration status during the process of measurement, as measured by the shift in the absorption wavenumber of the primary alcohol stretching vibration. In addition, Forms I and III could not be distinguished clearly by the X-ray powder diffraction and their crystalline forms were similar plate crystals. However, in the IR spectra by the attenuated total reflection (ATR) method, the three forms could be identified based on each characteristic absorption. In summary, the ATR method does not require pretreatment for sample analysis, can be performed quickly, and is thus suitable to identify crystalline polymorph forms such as pseudo-crystalline polymorphs of thiamine chloride hydrochloride, which transform easily depending on the hydration status in a measurement environment.
\end{abstract}

Key words - IR spectrophotometry; attenuated total reflection (ATR); crystalline polymorph; thiamine chloride hydrochloride

\section{緒言}

結晶多形は，同じ化合物であっても分子間相互作 用や固体表面分子の違いがみられ，医薬品において は安定性の変化, 溶解速度の変化などにより, 薬理 効果・毒性に影響を与える可能性がある。したがつ て，結晶多形を迅速かつ正確に識別できる分析手法 の開発は重要であり, 以前より様々な方法が研究さ れている.

チアミン塩化物塩酸塩を, 臭化カリウム（potassium bromide; KBr) 錠剤法により IR スペクトル を測定したところ，同一のサンプルを測定している

一般財団法人医薬品医療機器レギュラトリーサイエン

又財団医薬標準品センター

Tsuyoshi Tanimoto (Deceased.)

*e-mail: ayano-yamada@pmrj.jp
にもかかわらずスペクトルに再現性が認められず, 特に C-O 伸縮振動に帰属されるピークにおいて違 いが顕著であった.

チアミン塩化物塩酸塩は結晶水が関与した結晶多 形として, I 型 (1 水和物), II 型 (0.5 水和物) 及 び III 型（無水和物）の 3 種の擬似結晶多形（結晶 多形中に溶媒和物を含むもの）が知られており,

Fig. 1 に示したように取扱い環境の影響を受けて直 ちに転移することが報告されている. ${ }^{1-3)}$ II 型は加 熱することで III 型となるが，III 型は容易に吸湿 して I 型に転移することが報告されている. ${ }^{1)} ま$ た，チアミン塩化物塩酸塩の錠剤や顆粒を製造する 際にも，周囲環境の影響を受けて， III 型からすぐ に I 型に転移し，保管によって II 型に転移するこ

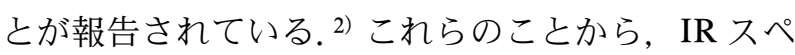
クトルに再現性が認められなかったのは，取扱い環 


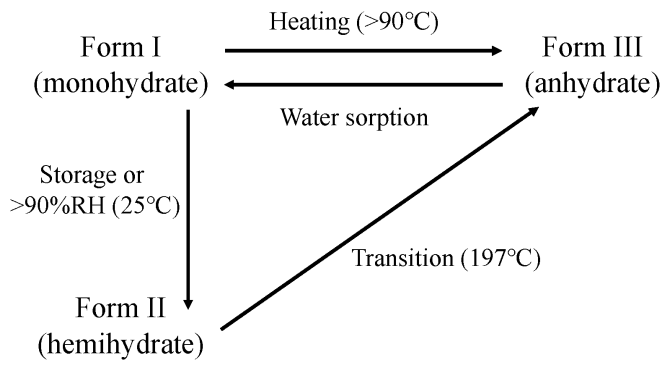

Fig. 1. Transition Diagram of the Three Forms of Pseudocrystalline Thiamine Chloride Hydrochloride

境の影響が原因である可能性が考えられた。また， これまで擬似結晶多形の転移については多くの研 究1-9)がなされてきたが，これら 3 種の擬似結晶多 形の識別確認方法が明確に示された研究事例は粉末 X 線回折 (X-ray powder diffraction; XRPD) 1,3,7-9) 以外にほとんどない。

そこで，XRPDより汎用性が高いIR スペクトル 測定法において，測定環境が擬似結晶多形の転移に ごのように影響を与えているかを 3 種の擬似結晶多 形を調製し，IR スペクトルにより確実に識別でき る方法の確立を目指した.

\section{方法}

1. 試料 チアミン塩化物塩酸塩（日本薬局方 標準品；一般財団法人医薬品医療機器レギュラト リーサイエンス財団，東京）を試料とした。 チアミ ン塩化物塩酸塩の化学構造式を分子式及び化学名と ともに Fig. 2 に示した.

2. 擬似結晶多形の調製 チアミン塩化物塩酸 塩の擬似結晶多形である I 型結晶 (1 水和物), II 型結晶（0.5 水和物）及び III 型結晶（無水和物） を Fig. 1 に示した転移条件 ${ }^{1-3)}$ を参考に調製した。 調製後，速やかに各測定に供した.

\section{2-1. I 型結晶（1 水和物） チアミン塩化物塩} 酸塩約 $0.6 \mathrm{~g}$ を直径約 $3 \mathrm{~cm}$ の秤量瓶にとり, 厚さ 約 $3 \mathrm{~mm}$ に広げ， $105^{\circ} \mathrm{C}$ で 2 時間乾燥した。飽和塩 化マグネシウム水溶液を用いて， $25^{\circ} \mathrm{C}$ 相対湿度約 $30 \%$ の環境をデシケーター内に調製し，その中に乾 燥したチアミン塩化物塩酸塩を 3 日間放置した。

\section{2-2. II 型結晶（0.5 水和物） チアミン塩化物} 塩酸塩約 $4.8 \mathrm{~g}$ を直径約 $6 \mathrm{~cm}$ の秤量瓶にとり, 厚 さ約 $7 \mathrm{~mm}$ に広げ，十分量の精製水を用いて， $25^{\circ} \mathrm{C}$ 相対湿度約 $90 \%$ の環境をデシケーター内に調製

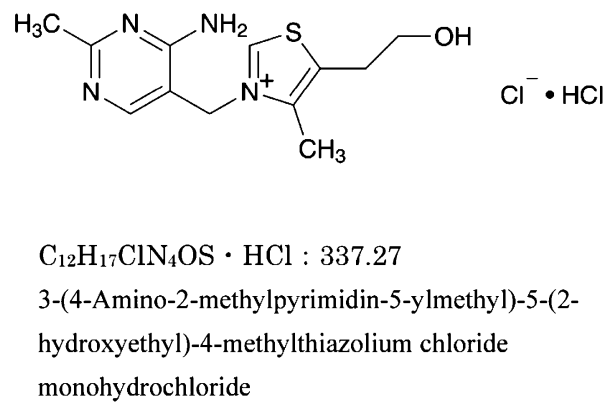

Fig. 2. Chemical Structure, Molecular Formula, and Chemical Name of Thiamine Chloride Hydrochloride

し，その中に 24 時間放置した. その後表面の付着 水を揮散させるため $105^{\circ} \mathrm{C}$ で 2 時間乾燥した.

2-3. III 型結晶（無水和物） チアミン塩化物 塩酸塩約 $0.6 \mathrm{~g}$ を直径約 $3 \mathrm{~cm}$ の秤量瓶にとり, 厚 さ約 $3 \mathrm{~mm}$ に広げ, $105^{\circ} \mathrm{C}$ で 2 時間乾燥した。

3. XRPD 調製した 3 種の擬似結晶多形につ き，それぞれ適量をサンプリングホルダーに入れ， 日本薬局方一般試験法粉末 X 線回折測定法に従い, X 線回折装置 X'Pert PRO MPD（スペクトリス株 式会社，川崎）により，ターゲット $\mathrm{Cu}, \mathrm{X}$ 線管電

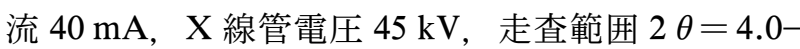
$40.0^{\circ}$ で測定した.

4. 性状（結晶の顕微鏡写真）調製した 3 種 の擬似結晶多形につき，それぞれ約 $3 \mathrm{mg}$ を用いて 顕微鏡 SGT-600 MBh（株式会社島津理化，東京） により結晶を観察した。また，結晶の顕微鏡写真を 顕微鏡デジタルカメラシステム Moticam 2（株式会 社島津理化, 東京) を用いて撮影（150 倍）した.

5. 熱重量·示差熱分析 (thermogravimetry and differential thermal analysis; TG-DTA） 調製した 3 種の擬似結晶多形につき，それぞれ約 $10 \mathrm{mg}$ をア ルミマクロセルに入れ，TG-DTA 同時測定装置 DTG-60（株式会社島津製作所，京都）により，窒 素気流中, 昇温速度 $5^{\circ} \mathrm{C} / \mathrm{min}$ で室温から $280^{\circ} \mathrm{C}$ の 温度範囲で測定した。

6. 水分 [カールフィッシャー (Karl Fischer; KF) 法】調製した 3 種の擬似結晶多形につき，それ ぞれ約 $30 \mathrm{mg}$ を用い, 微量水分測定装置 AQ-2200 （株式会社 HIRANUMA，水戸）により，日本薬局 方一般試験法水分測定法に従い測定した。陽極液に アクアライトRS (株式会社 HIRANUMA，水戸), 陰極液にアクアライト CN（株式会社 HIRANU- 


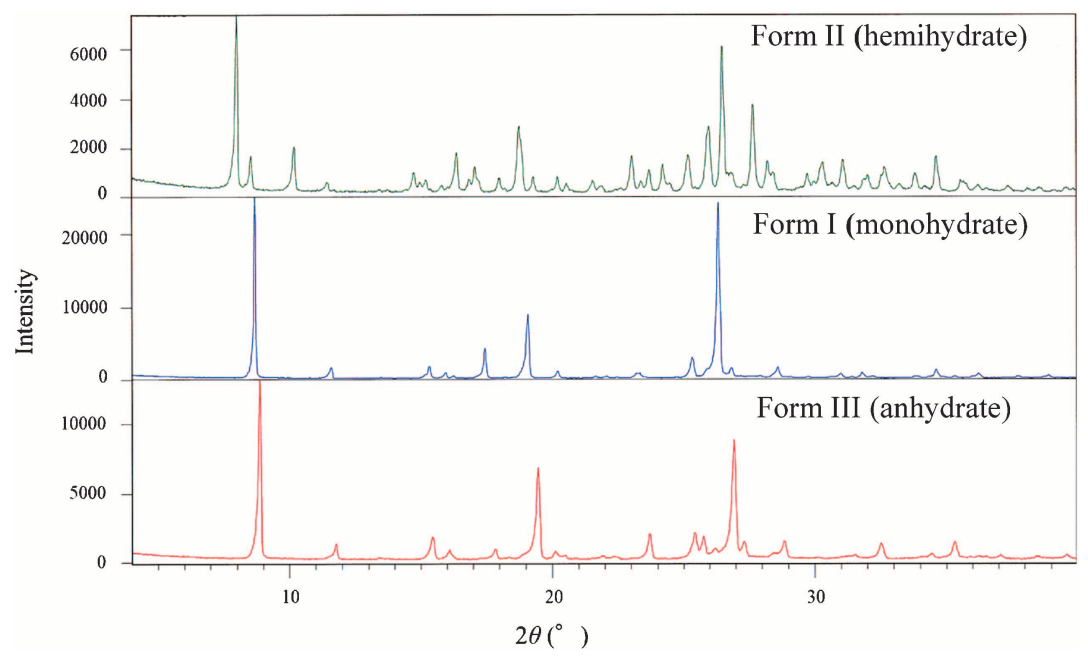

Fig. 3. XRPD Patterns of the Three Forms of Pseudo-crystalline Thiamine Chloride Hydrochloride (Forms I, II, and III)

MA，水戸）を用いた.

7. IR スペクトル [塩化カリウム（potassium chloride; KCl）錠剂法］日本薬局方一般試験法 赤外吸収スペクトル測定法に従い， $500^{\circ} \mathrm{C}$ で 5 時間 乾燥させた IR 吸収測定用 $\mathrm{KCl}$ (富士フイルム和光 純薬株式会社，大阪）約 $0.2 \mathrm{~g}$ に，調製した 3 種の 擬似結晶多形につき，それぞれ約 $1 \mathrm{mg}$ を擦り混ぜ て錠剤を形成し，フーリエ変換赤外分光光度計 IR Affinity-1（株式会社島津製作所，京都）を用いて 測定した。未乾燥の IR 吸収測定用 $\mathrm{KCl}$ を用いた測 定は， $500^{\circ} \mathrm{C}$ で 5 時間乾燥していない IR 吸収測定 用 $\mathrm{KCl}$ を用いて，同様に錠剤を形成して行った。

\section{IR スペクトル［減衰全反射測定（attenuated} total reflection; ATR) 法］日本薬局方一般試験 法赤外吸収スペクトル測定法に従い，フーリエ変換 赤外分光光度計 IR Affinity-1（株式会社島津製作 所，京都）に 1 回反射 ATR 装置 Quest（Specac, London）を取り付け，調製した 3 種の擬似結晶多 形につき，それぞれ適量をサンプリングホルダーに 入れ，測定した。

\section{結果}

\section{1. 擬似結晶多形の作製}

1-1. XRPD 調製したチアミン塩化物塩酸塩 の I 型， II 型及び III 型結晶につき，それぞれ XRPD により回折パターンを測定した結果を Fig. 3 に示した. 回折パターンについては，これまで報 告があり,1,3-5,7-9) それらの結果と比較すると，II 型
結晶については報告されている回折パターンとほぼ 一致し，主な $2 \theta$ は， $8.0^{\circ} ， 10.2^{\circ}$ 及び $27.7^{\circ}$ であっ た。一方，I 型及び III 型の結晶の回折パターンは 非常に類似していたものの，異なる擬似結晶多形で あることが確認できた。主な $2 \theta$ は，それぞれ I 型 結晶では $8.7^{\circ}$ 及び $26.3^{\circ}$ ， III 型結晶においては $8.9^{\circ}$ 及び $26.9^{\circ}$ であった。しかし，過去の報告1)では $2 \theta$ に I 型結晶の $26.3^{\circ}$ ， III 型結晶の $26.9^{\circ}$ が確認さ れておらず，今回の結果とは完全には一致しなかっ た.

1-2. 性状（結晶の顕微鏡写真）調製したチ アミン塩化物塩酸塩の 3 種の擬似結晶多形の顕微鏡 写真を Fig. 4 に示した。I 型及び III 型結晶は，い ずれも板状結晶であり類似した結晶であった。一方，

II 型結晶は，I 型及び III 型結晶と異なり微細な針 状結晶であった。

1-3. TG-DTA 調製したチアミン塩化物塩酸 塩の I 型，II 型及び III 型結晶につき，それぞれ TG-DTA を測定した結果を Fig. 5 に示した. I 型結 晶は， $236^{\circ} \mathrm{C}$ において吸熱ピークが認められ，水分 が 3.9\%の減量として認められた。1 水和物に近い 水分量（理論值 $5.1 \%$ ）であった。 III 型結晶も, 同じく $236^{\circ} \mathrm{C}$ において吸熱ピークが認められたが, 減量はわずか $0.5 \%$ であったことから，無水和物で あることを示唆する結果であった。一方，II 型結

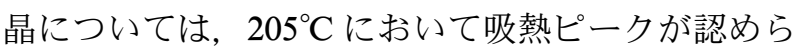
れ，水分が $1.2 \%$ の減量として認められたが， 0.5 水和物に相当する水分量（理論値 $2.5 \%$ ）ではな 


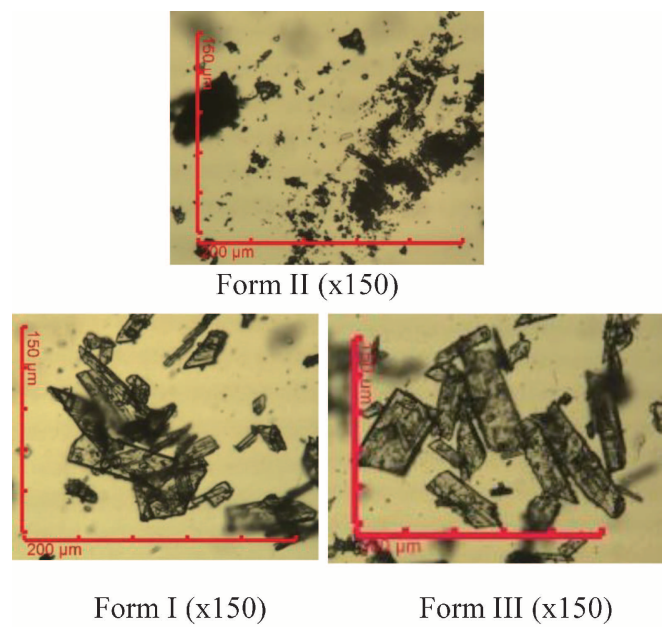

Fig. 4. Photomicrographs of the Three Forms of Pseudocrystalline Thiamine Chloride Hydrochloride (Forms I, II, and III)

(A) Form II

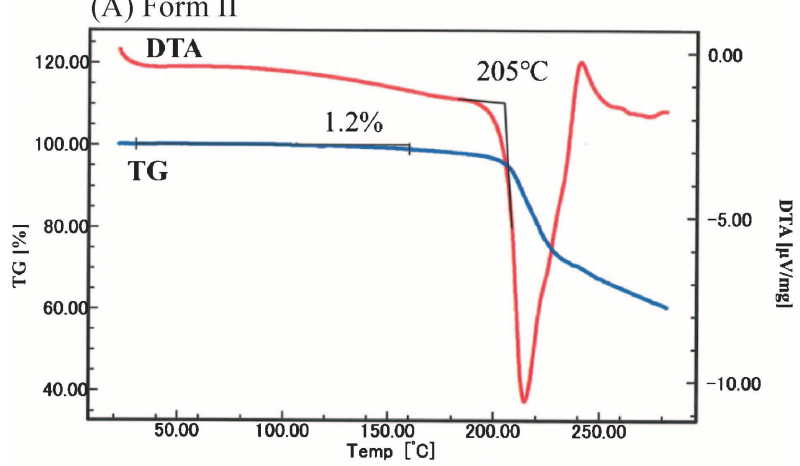

(B) Form I

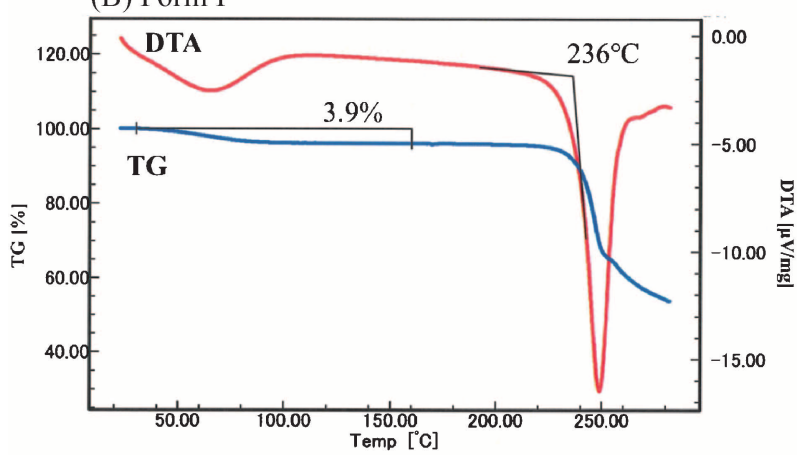

(C) Form III

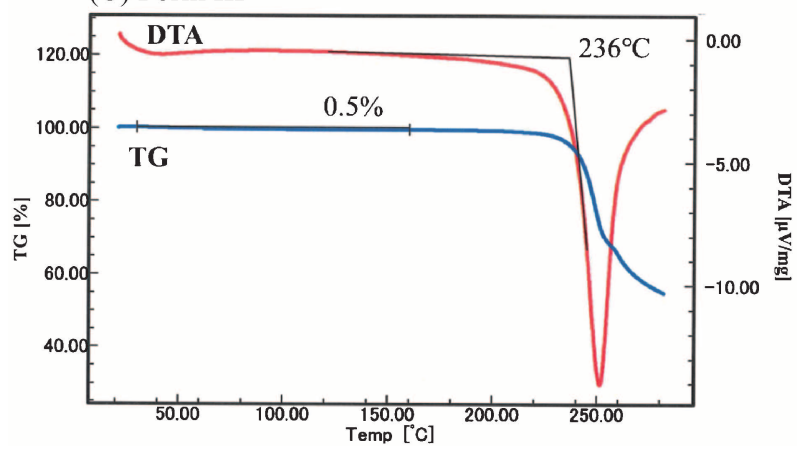

Fig. 5. TG-DTA Curves of the Three Forms of Pseudocrystalline Thiamine Chloride Hydrochloride Sample: (A), Form II; (B), Form I; (C), Form III.
Table 1. Water Contents of the Three Forms of Pseudocrystalline Thiamine Chloride Hydrochloride (Forms I, II, and III)

\begin{tabular}{cccc}
\hline \hline & $\begin{array}{c}\text { Form II } \\
\text { (hemihydrate) }\end{array}$ & $\begin{array}{c}\text { Form I } \\
\text { (monohydrate) }\end{array}$ & $\begin{array}{c}\text { Form III } \\
\text { (anhydrate) }\end{array}$ \\
\hline Water (KF) & $2.3 \%$ & $4.3 \%$ & $0.2 \%$ \\
\hline
\end{tabular}

かつた。これは II 型結晶である水和物結晶は，非 常に安定に存在し，I 型及び III 型結晶には容易に 転移しないことを示唆する結果であった。また，こ れらの結果は，Fig. 1 に示した転移相関図を支持す るものであった。

1-4. 水分（KF 法） 調製したチアミン塩化物 塩酸塩の I 型， II 型及び III 型結晶につき，それぞ れ KF 法により水分を測定した結果を Table 1 に示 した。I 型結晶は水分值 $4.3 \%$ ＩI 型結晶は水分値 $2.3 \%$ であり，それぞれ 1 水和物（理論值 $5.1 \%$ ), 0.5 水和物（理論值 $2.5 \%$ ）に近い水分が観測され た．III 型結晶は水分値 $0.2 \%$ でったことから無 水和物であることを示唆する結果であった.

以上の結果から，調製した I 型，II 型及び III 型 結晶は，それぞれ期待通りの結晶形が調製できたと 判断した.

\section{IR スペクトル（KCl 錠剤法及び ATR 法)}

調製したチアミン塩化物塩酸塩の I 型， II 型及び III 型結晶につき， $\mathrm{KCl}$ 錠剤法及び ATR 法により， IR スペクトルを測定した.

$\mathrm{KCl}$ 錠剤法による IR スペクトルを Fig. 6 に示し た． I 型及び III 型結晶については，水和物の違い からチアミン塩化物塩酸塩の第一アルコールの $\mathrm{C}-\mathrm{O}$ 伸縮振動は異なる波数に観測されるはずであ るが，それぞれ $1053 \mathrm{~cm}^{-1}$ 及び $1055 \mathrm{~cm}^{-1}$ に観測 され，両者の識別ができなかった．II 型結晶では， $1047 \mathrm{~cm}^{-1}$ 及び $790 \mathrm{~cm}^{-1}$ に特徵的な吸収が観測さ れ，報告1)とも一致した。

一方，ATR 法においては，Fig. 7 に示したよう に，I 型及び III 型結晶において第一アルコール の C-O 伸縮振動が，それぞれ $1042 \mathrm{~cm}^{-1}$ 及び $1054 \mathrm{~cm}^{-1}$ と異なる波数に観測され，両者を明確に 識別できるスペクトルが得られた。なお，II 型結 晶については，ATR 法においても， $1045 \mathrm{~cm}^{-1}$ 及 び $789 \mathrm{~cm}^{-1}$ に特徵的な吸収を示し, $\mathrm{KCl}$ 錠剤法, ATR 法のいずれの方法においても識別が可能で 
(A) Form II

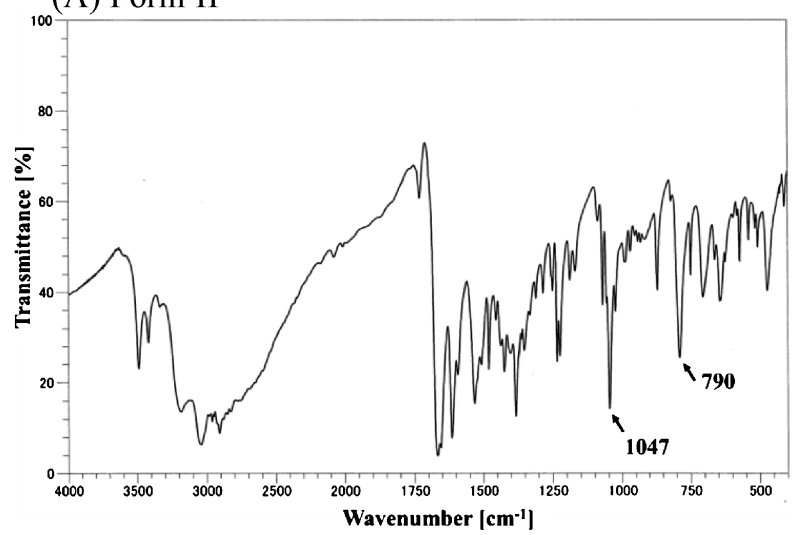

(B) Form I

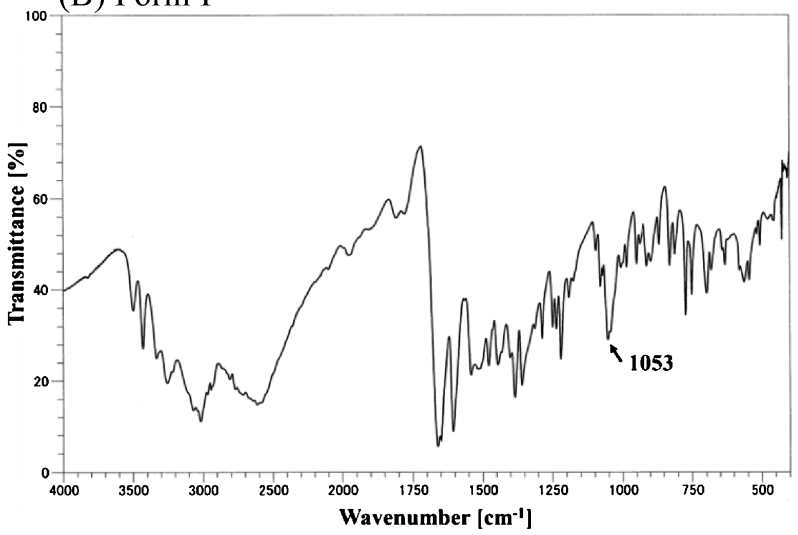

(C) Form III

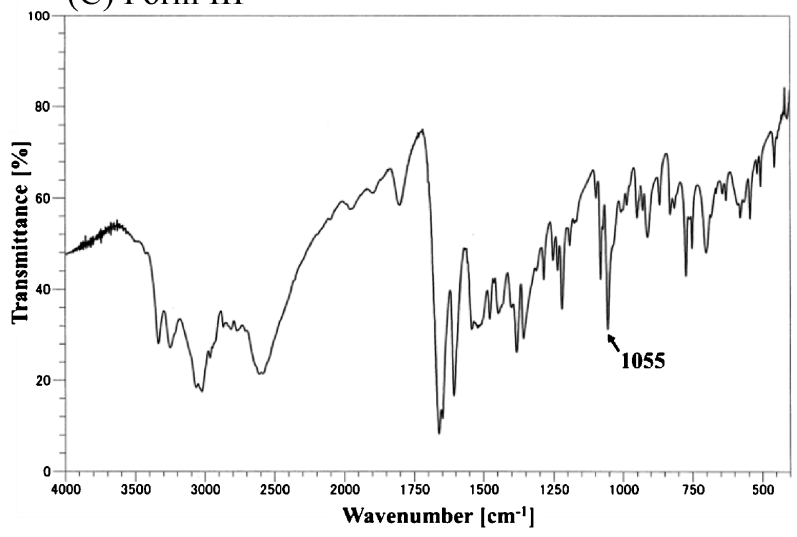

Fig. 6. IR Spectra Generated Using the $\mathrm{KCl}$ Disk Method of the Three Forms of Pseudo-crystalline Thiamine Chloride Hydrochloride

Sample: (A), Form II; (B), Form I; (C), Form III.

あった。

I 型結晶は IR スペクトルにおいて， $\mathrm{KCl}$ 錠剂法 及び ATR 法で異なる結果が得られた。チアミン塩 化物塩酸塩の擬似結晶多形は，取扱い環境の影響を 受けて直ちに転移することが報告されており, 2,3 測 定環境の影響を受けて 2 つ測定法により異なるス ペクトルが観測された可能性があった. 1 水和物で ある I 型結晶は， $\mathrm{KCl}$ 錠剤法で測定するとき，錠剤
(A) Form II

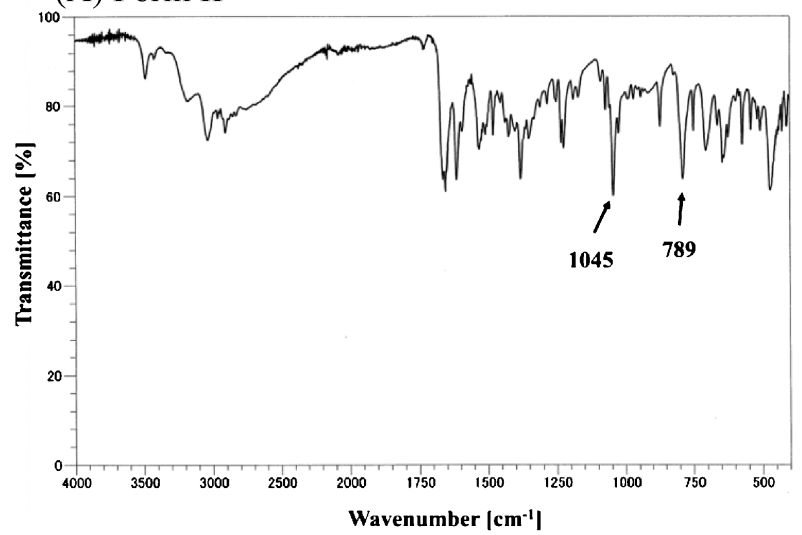

(B) Form I

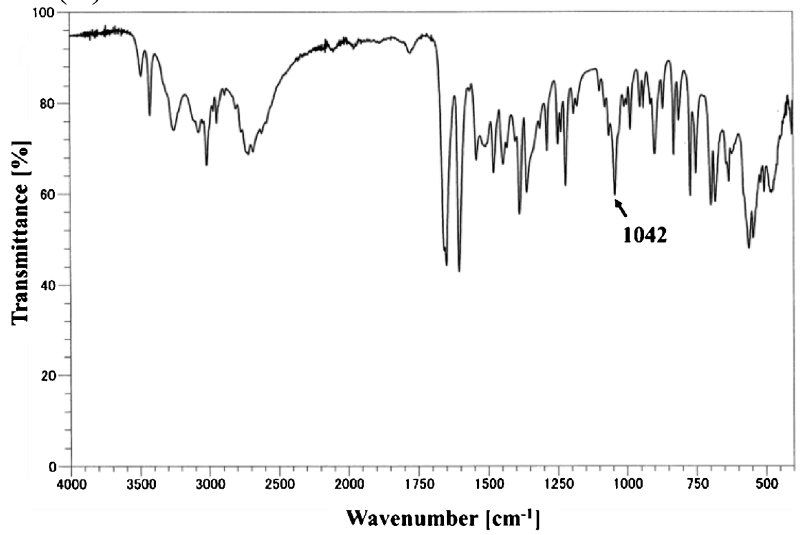

(C) Form III

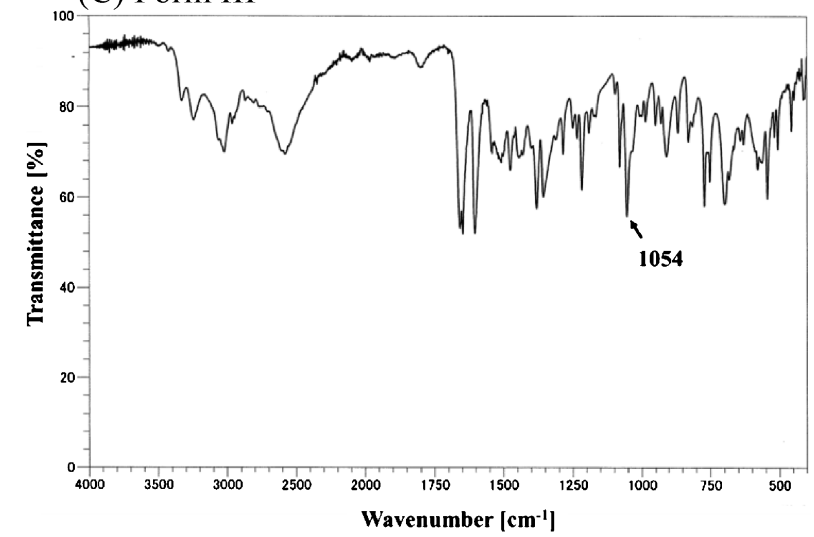

Fig. 7. IR Spectra Generated Using the ATR Method of the Three Forms of Pseudo-crystalline Thiamine Chloride Hydrochloride

Sample: (A), Form II; (B), Form I; (C), Form III.

形成中に乾燥した IR 吸収測定用 $\mathrm{KCl}$ とチアミン塩 化物塩酸塩との間で水分の移行が起こる可能性が考 えられたため，I 型結晶を用いて検討した。 日本薬 局方においては， $\mathrm{KCl}$ 錠剤法に用いる $\mathrm{KCl}$ は，あ らかじめ $500^{\circ} \mathrm{C}$ で 5 時間乾燥することとなっている が，IR 吸収測定用 $\mathrm{KCl}$ を未乾燥のまま錠剤形成し， $\mathrm{KCl}$ 錠剤法により I 型結晶の IR スペクトルを測定 
(A) With dried $\mathrm{KCl}$ powder

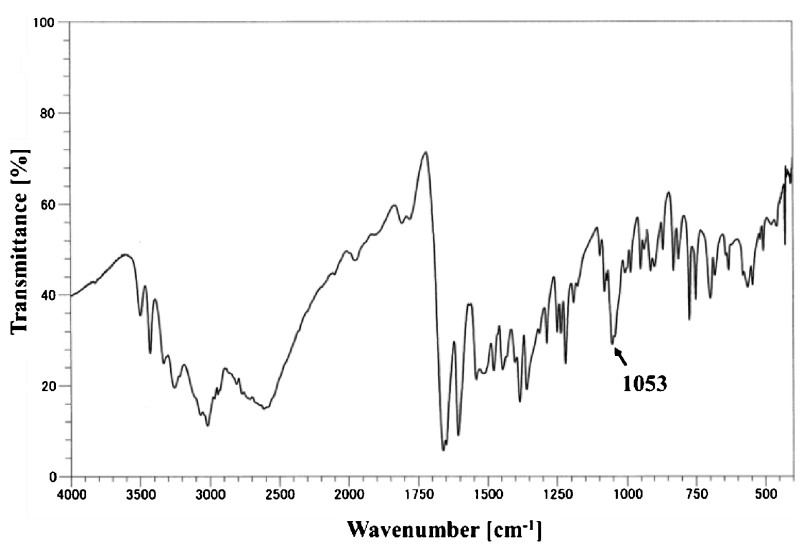

(B) With undried $\mathrm{KCl}$ powder

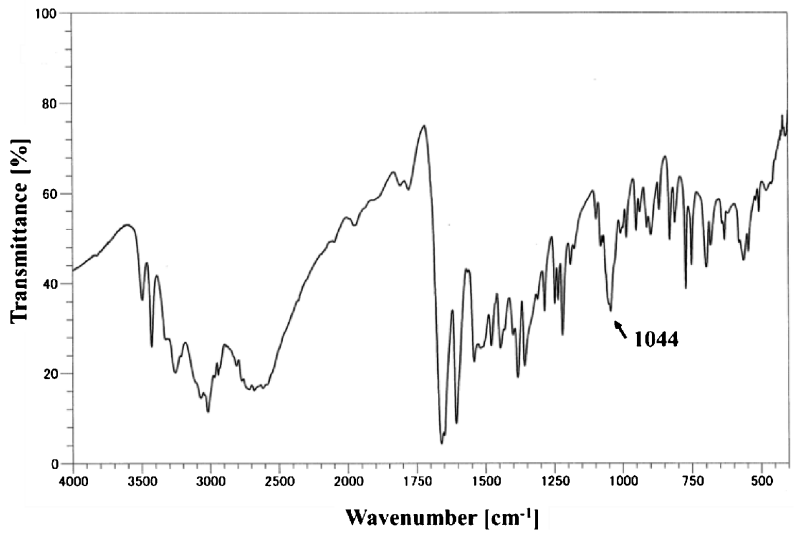

Fig. 8. IR Spectra Generated Using the $\mathrm{KCl}$ Disk Method of Form I Pseudo-crystalline Thiamine Chloride Hydrochloride Mixed with Dried (A) and Undried (B) $\mathrm{KCl}$ Powder

した. Figure 8 に示したように, 未乾燥の IR 吸収測 定用 $\mathrm{KCl}$ を用いた場合は I 型結晶の第一アルコー ルの C-O 伸縮振動に由来する吸収が $1044 \mathrm{~cm}^{-1}$ に 観測され，ATRの結果と一致した。この結果から， $\mathrm{KCl}$ 錠剤法で I 型結晶の IR スペクトルを測定する と, I 型結晶の水分が乾燥した $\mathrm{KCl}$ に移行し，無水 和物の III 型結晶に転移していることが示唆された.

測定環境の影響を受け，I 型結晶から III 型結晶 に容易に転移することが示唆されたことから，III 型結晶も測定環境の影響を受けて容易に I 型結晶に 転移することが考えられた。この点を確認するため,

III 型結晶を測定環境 $\left(24.5^{\circ} \mathrm{C}\right.$ ，相対湿度 $\left.29 \%\right)$ で 10 分間放置した後, ATR 法で測定した. Figure 9 に示したように, 10 分間放置した後に測定した IR スペクトルは，放置前に測定した IR スペクトルと 差がみられ，第一アルコールの C-O 伸縮振動を示 す波数が $1054 \mathrm{~cm}^{-1}$ から $1044 \mathrm{~cm}^{-1}$ に変化したこ
(A)

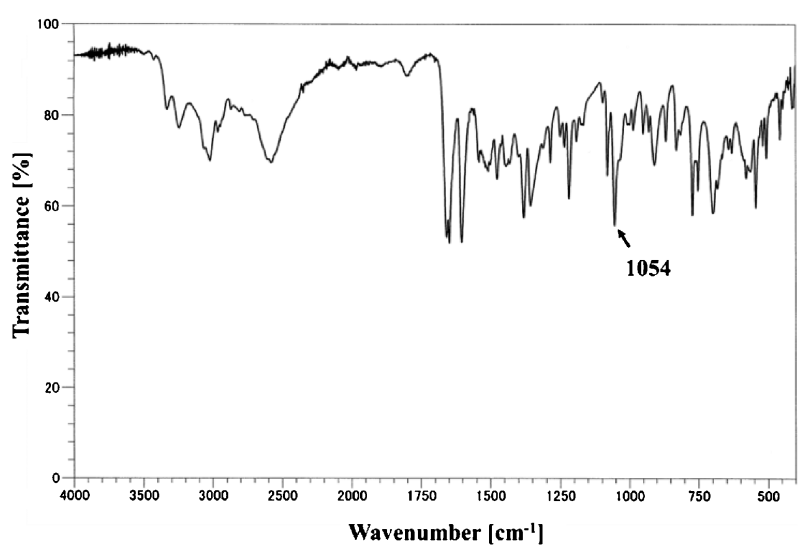

(B)

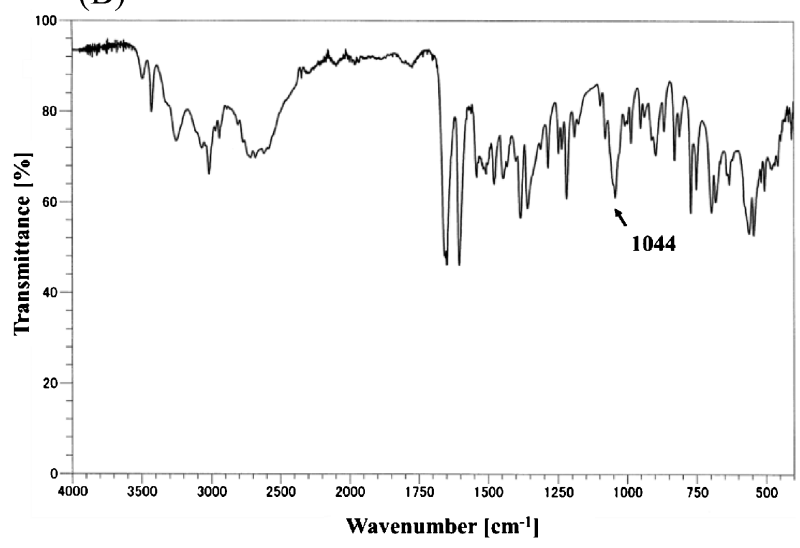

Fig. 9. IR Spectra Generated Using the ATR Method of Form III Pseudo-crystalline Thiamine Chloride Hydrochloride

Sample: (A), untreated; (B), left at $24.5^{\circ} \mathrm{C}$ in $29 \%$ relative humidity for $10 \mathrm{~min}$.

とから，III 型結晶から速やかに I 型結晶に転移し たことを確認した.

\section{考察}

1. 擬似結晶多形の調製 チアミン塩化物塩酸 塩の I 型, II 型及び III 型の 3 種の擬似結晶多形に つき，今回測定した結果のまとめを Table 2 に示し た。性状，XRPD，TG-DTA 及び水分（KF 法）の 結果より, チアミン塩化物塩酸塩の I 型, II 型及び III 型の 3 種の擬似結晶多形が調製できていること が確認できた。

ただし，XRPD においては，II 型結晶について は特徵的な回折パターンが観測できたが，I 型及び III 型結晶は異なる擬似結晶多形であることが確認 できたものの，非常に回折パターンが類似していた ことから, 結晶構造の類似性が高いと推定された。 
Table 2. Summary of the Physicochemical Data of the Three Forms of Pseudo-crystalline Thiamine Chloride Hydrochloride (Forms I, II, and III)

\begin{tabular}{|c|c|c|c|}
\hline & Form II (hemihydrate) & Form I (monohydrate) & Form III (anhydrate) \\
\hline Description & Fine-needle crystals & Plate crystals & Plate crystals \\
\hline \multirow{2}{*}{ IR ( $\mathrm{KCl}$ Disk) $\mathrm{cm}^{-1}$} & 1047 & 1053 (with dried $\mathrm{KCl}$ powder) & 1055 \\
\hline & 790 & 1044 (with undried $\mathrm{KCl}$ powder) & \\
\hline \multirow{2}{*}{ IR $(\mathrm{ATR}) \mathrm{cm}^{-1}$} & 1045 & 1042 & 1054 (untreated) \\
\hline & 789 & & 1044 (left for $10 \mathrm{~min}$ ) \\
\hline \multirow{3}{*}{ XRPD $(2 \theta)$} & $8.0^{\circ}$ & $8.7^{\circ}$ & $8.9^{\circ}$ \\
\hline & $10.2^{\circ}$ & $26.3^{\circ}$ & $26.9^{\circ}$ \\
\hline & $27.7^{\circ}$ & & \\
\hline TG & weight loss: $1.2 \%$ & weight loss: $3.9 \%$ & weight loss: $0.5 \%$ \\
\hline DTA & $205^{\circ} \mathrm{C}$ (endothermic) & $236^{\circ} \mathrm{C}$ (endothermic) & $236^{\circ} \mathrm{C}$ (endothermic) \\
\hline Water (KF) & $2.3 \%$ & $4.3 \%$ & $0.2 \%$ \\
\hline
\end{tabular}

さらに，I 型及び III 型結晶の性状（結晶の写真） において，II 型結晶においては微細な針状結晶で あったが，I 型結晶及び III 型結晶においてはいず れも類似した板状結晶であった．TG-DTA 測定に おいても II 型結晶については, 特徵的な TG-DTA 曲線を示したが，I 型結晶及び III 型結晶において は, 水分相当量の減量の違いはあるものの TGDTA 曲線は非常に類似した結果であり，両者の結 晶形の識別が困難であった。 I 型結晶が加熱により 水分が抜け，III 型結晶に転移したと推定され，そ のことが TG-DTA 曲線が類似した原因と考えられ た.

\section{IR スペクトル（KCI 錠剤法及び ATR 法）}

チアミン塩化物塩酸塩は塩酸塩であることから, IR 測定で汎用されている $\mathrm{KBr}$ 錠剤法を用いた場合 には，塩交換によりスペクトル変化が起こる恐れが ある.このことから日本薬局方では, 第十七改正日 本薬局方で各条「チアミン塩化物塩酸塩」の確認試 験は $\mathrm{KBr}$ 錠剂法から $\mathrm{KCl}$ 錠剤法に改正されてい る。われわれがチアミン塩化物塩酸塩を $\mathrm{KBr}$ 錠剂 法により IR スペクトルを測定したとき, $1040 \mathrm{~cm}^{-1}$ から $1050 \mathrm{~cm}^{-1}$ 付近の吸収が測定回ごとに異な り，再現性のよいスペクトルが得られなかった。原 因として塩交換の影響が考えられたが，チアミン塩 化物塩酸塩を $\mathrm{KBr}$ 錠剂法及び $\mathrm{KCl}$ 錠剂法で測定し たスペクトルに差はなかったことから，IR スペク トルに再現性が得られないのは塩交換が原因ではな いことが明らかになった（デー夕は示さず）.

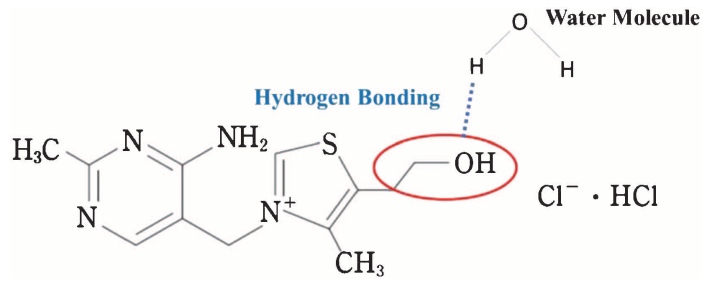

Fig. 10. Hydrogen Bonding Mode between the Primary Alcohol of Thiamine Chloride Hydrochloride and Water Molecule

Table 2 に示したように， $\mathrm{KCl}$ 錠剤法で測定した IR スペクトルにおいて，II 型結晶には特徵的な吸 収帯が認められたが，I 型及び III 型結晶は類似 したスペクトルが得られ，特に $1040 \mathrm{~cm}^{-1}$ から $1050 \mathrm{~cm}^{-1}$ 付近の吸収が測定回ごとに異なり，再現 性のあるスペクトルを得ることはできなかった。こ れは，チアミン塩化物塩酸塩の第一アルコールの $\mathrm{C}-\mathrm{O}$ 伸縮振動を示す波数は $1054 \mathrm{~cm}^{-1}$ 付近である が，第一アルコールは水と水素結合することから (Fig. 10), 水の有無により第一アルコールの C-O 伸縮振動を示す波数が変化している可能性が考えら れた。また， I 型結晶は $\mathrm{KCl}$ 錠剤法と ATR 法で異 なるIR スペクトルが得られた。

XRPD の結果において，I 型及び III 型結晶は非 常に類似した回折パターンであったこと，また I 型 及び III 型結晶は類似した板状結晶であること，さ らに I 型結晶は 1 水和物であり III 型結晶は無水和 物であることから，錠剤形成時に環境の影響，特に 水分の影響を受けて，相互に転移が起きている可能 
性が考えられた。これを確認するために，I 型結晶 を用いて検討を行った。 IR 吸収測定用 $\mathrm{KCl}$ を未乾 燥のまま錠剤形成し， $\mathrm{KCl}$ 錠剤法により IR スペク トルを測定した結果，Fig. 8 に示したように，未乾 燥の IR 吸収測定用 $\mathrm{KCl}$ を用いた場合は I 型結晶の 第一アルコールの C-O 伸縮振動として $1044 \mathrm{~cm}^{-1}$ に観測された。このことから，乾燥した IR 吸収測 定用 $\mathrm{KCl}$ を使用した場合は，錠剤形成時にチアミ ン塩化物塩酸塩と IR 吸収測定用 $\mathrm{KCl}$ の間で水分の 移動が起こり， 1 水和物である I 型結晶から無水和 物である III 型結晶に転移したことが示唆された。 また，逆に III 型結晶から I 型結晶への転移につい て ATR 法を用いて検討した結果，Fig. 9 に示した ように，I 型結晶を ATR 法で測定したときの IR ス ペクトルと同様の結果が得られ，無水和物である III 型結晶は，第一アルコールの C-O 伸縮振動を示 す波数が $1054 \mathrm{~cm}^{-1}$ から $1044 \mathrm{~cm}^{-1}$ に変化した. これは無水和物から水和物に変化したことから，チ アミン塩化物塩酸塩の第一アルコールと水との水素 結合（Fig. 10）により約 $10 \mathrm{~cm}^{-1}$ ほど低波数へシ フトしたものと推定された。このことから，一般的 な実験室の環境 $\left(25^{\circ} \mathrm{C}\right.$, 相対湿度 $30 \%$ 付近）で, III 型結晶は速やかに I 型結晶に転移していること が示唆され，無水和物である III 型結晶は吸湿性が 非常に高く，急速に I 型結晶へと転移すると推定さ れた。

以上の結果から，一般的な実験室の環境 $\left(25^{\circ} \mathrm{C}\right.$, 相対湿度 $30 \%$ 付近）において I 型及び III 型結晶は 水分の影響を受けて容易に転移するため, $\mathrm{KBr}$ 錠 剂法及び $\mathrm{KCl}$ 錠剂法で IR スペクトルを測定したと き，再現性が得られなかったと考えられた。

$\mathrm{KBr}$ 錠剂法や $\mathrm{KCl}$ 錠剂法と比較し，前処理が不 要で迅速に測定が可能な ATR 法は，比較的新しい 測定方法であり，チアミン塩化物塩酸塩の擬似結晶 多形を ATR 法により識別した方法についてはまだ 報告されていない. Figure 7 に示したように, ATR 法の場合， 3 種の擬似結晶多形を識別して観 測することができた。錠剤法と異なり，ATR 法は サンプリングから測定までの操作時間が短いため, 転移が起きる前に測定することができ，3 種の I 型， II 型及び III 型の擬似結晶多形を識別して観測でき
ることが明らかになった。

以上のことから, チアミン塩化物塩酸塩のように 取扱い環境によって結晶形が転移し易い物質におい ては，物理的処理を行い，調製に時間がかかる錠剂 法による IR スペクトルでは，正確な識別が困難な 場合があるが，物理化学的に処理を加えることなく 迅速に測定ができる ATR 法は，擬似結晶多形の確 認方法として有効であると考えられた.

謝辞本研究にあたりまして, 粉末 X 線回折 のデータ取得及びご指導頂きました株式会社住化分 析センター山崎真弥子氏に深謝致します。この研究 を遂行するにあたり，終始暖かく見守って下さった 故・谷本 剛医薬標準品センター長には，心から感 謝申し上げます。

\section{利益相反＼cjkstart開示すべき利益相反はない.}

\section{REFERENCES}

1) Watanabe A., Nakamachi H., Yakugaku Zasshi, 96, 1236-1240 (1976).

2) Wöstheinrich K., Schmidt P. C., Drug Dev. Ind. Pharm., 27, 481-489 (2001).

3) Masuda K., Ishige T., Yamada H., Fujii K., Uekusa H., Miura K., Yonemochi E., Terada K., Chem. Pharm. Bull., 59, 57-62 (2011).

4) Watanabe A., Tasaki S., Wada Y., Nakamachi H., Chem. Pharm. Bull., 27, 2751-2759 (1979) .

5) Watanabe A., Kanzawa T., Okuto H., Yakugaku Zasshi, 79, 883-886 (1959).

6) Masuda K., J. Soc. Powder Technol., Japan, 43, 41 (2006).

7) Te R. L., Griesser U. J., Morris K. R., Byrn S. R., Stowell J. G., Cryst. Growth Des., 3, 9971004 (2003).

8) Chakravarty P., Berendt R. T., Munson E. J., Young V. G. Jr., Govindarajan R., Suryanarayanan R., J. Pharm. Sci., 99, 816-827 (2010) .

9) Chakravarty P., Berendt R. T., Munson E. J., Young V. G. Jr., Govindarajan R., Suryanarayanan R., J. Pharm. Sci., 99, 18821895 (2010). 